\title{
Model Asuhan Keperawatan pada Klien dengan Abortus Inkomplet Menggunakan Pendekatan Need for Help Wiedenbach dan Self Care Orem
}

\section{Tutik Rahayu 1}

1Fakultas Ilmu Keperawatan Universitas Islam Sultan Agung Semarang

\section{Article Info}

\section{Article History:}

Accepted November 23rd 2018

\section{Key words:}

Teori model Need for help Wiedenbach dan self care Orem, Abortus Inkomplet

\begin{abstract}
Abortus merupakan salah satu bentuk komplikasi dalam kehamilan. Penerapan asuhan keperawatan pada klien dengan abortus inkomplet menggunakan Teori "Need for help". Menurut Wiedenbach keperawatan klinik (clinical nursing) mempunyai empat komponen, yaitu filsafat (philosophy), kemanfaatan/kegunaan (purpose), praktik, dan kiat (art). Pada klien yang mengalami abortus inkomplet, klien datang ke rumah sakit dengan keluhan diantarnya adanya perdarahan. Perdarahan cenderung lebih banyak dari darah menstruasi dan kadang berlebihan yang dapat menyebabkan syok. Klien Kondisi pada klien tersebut tentu harus segera mendapatkan pertolongan agar klien dapat selamat dan terhindar dari komplikasi dan kematian, sehingga "Need for help" tepat digunakan pada klien yang mengalami abortus inkomplet. Selain menggunakan konsep teori need for help pada klien dengan abortus inkomplit juga menggunakan teori self care yang dikembangkan oleh Orem. self care merupakan kemampuan individu untuk memprakarsai dirinya dalam melakukan perawatan diri sendiri dalam rangka mempertahankan kehidupan, kesehatan dan kesejahteraan. Self care yang dilakukan secara efektif dapat membantu menjaga fungsi tubuh serta berkontribusi seperti pada perkembangan individu. Supportif educatif yang diberikan pada klien dengan abortus inkomplet dapat meningkatkan pengetahuan klien tentang kesehatan reproduksi seperti mempersiapkan kondisi baik fisik dan mental pada kehamilan yang akan datang.
\end{abstract}

\section{PENDAHULUAN}

Tingginya angka kematian maternal dan perinatal masih menjadi masalah yang besar di dunia. Dilaporkan bahwa kematian maternal diakibatkan oleh berbagai komplikasi selama kehamilan, persalinan, dan nifas. Abortus merupakan salah satu bentuk komplikasi dalam kehamilan.
Abortus berhubungan dengan berbagai faktor yaitu faktor ibu 65\%, faktor janin $20 \%$, dan faktor plasenta 15\%. Diantara ketiga faktor tersebut, penyebab paling banyak terjadinya abortus adalah faktor ibu yang meliputi umur, paritas, anemia, penyakit ibu, dan sosial ekonomi (Sugiarti, 2010).

Corresponding author:

Tutik Rahayu

tutikrahayu02@gmail.com

Jurnal Ilmu Keperawatan Maternitas, Vol 1 No 2, Nov 2018

e-ISSN 2621-2994 
Jurnal Ilmu Keperawatan Maternitas, Vol 1 No 2, Nov 2018/ page 31-42

Ada tiga penyebab klasik kematian ibu yaitu perdarahan, keracunan kehamilan dan infeksi. Sebenarnya ada penyebab ke 4 yaitu abortus. Menurut Organisasi Kesehatan Dunia (WHO) 15-50\% kematian ibu disebabkan oleh abortus. Komplikasi abortus berupa perdarahan atau infeksi dapat menyebabkan kematian. Itulah sebabnya rnengapa kematian ibu yang disebabkan abortus sering tidak muncul dalam laporan kematian, tapi dilaporkan sebagai perdarahan atau sepsis (Azhari, 2002, Abraham, 2010).

Abortus inkompletus adalah berakhirnya kehamilan sebelum janin cukup berkembang untuk hidup diluar kandungan terdapat sisa jaringan yang masih tetinggal didalam rahim dengan usia kehamilan kurang dari 20 minggu dan berat janin kurang dari 500 gram (Noerjasin, Kuswano, Wirakusumah, 2010).

Perempuan yang mengalami abortus sering menunjukan respon psikologis seperti rasa kehilangan, depresi dan kecemasan (Rowsell, Kricmaerr \& Osford, 2001). Ada beberapa penelitian melaporkan mengenai reaksi psikologis abortus diantaranya muncul reaksi psikologis pada wanita pasca abortus meliputi rasa bersalah (61\%),depresi $(52,5 \%)$, menyesal $(52,1 \%)$, malu (52\%), sedih (55,3\%) (Mardiyah, Prawiroharjo,Tiro, 2011).

Penerapan asuhan keperawatan pada klien dengan abortus inkomplet menggunakan Teori "Need for help" Wiedenbach Perhatian utama teori Ernestine Wiedenbach adalah kepeda aspek kiat (praktik) dari keperawatan. Menurut Wiedenbach keperawatan klinik (clinical nursing) mempunyai empat komponen, yaitu filsafat (philosophy), kemanfaatan/kegunaan (purpose), praktik, dan kiat (art). Pandangan ini yang melandasi pendapatnya bahwa pada praktik keperawatan terdapat tiga kegiatan, yaitu mengidentifikasi kebutuhan pasien, melaksanakan bantuan yang diperlukan, mengevaluasi dan menyatakan (mensyahkan) bahwa bantuan yang diberikan memang bermanfaat (Wiedenbach, 1963).

Pada klien yang mengalami abortus inkomplet, klien datang ke rumah sakit dengan keluhan diantaranya adanya perdarahan. Perdarahan cenderung lebih banyak dari darah menstruasi dan kadang berlebihan yang dapat menyebabkan syok. Selama jaringan sisa tetap melekat pada sebagian dinding uterus maka kontraksi miometrium akan terganggu. Nyeri kram suprapupik terjadi akibat kontraksi uterus dalam usaha mengeluarkan isi uterus. Mulamula nyeri cenderung ringan intermiten tetapi secara bertahap menjadi lebih hebat (Qunynh, 2011). Kondisi pada klien tersebut tentu harus segera mendapatkan pertolongan agar klien dapat selamat dan terhindar dari komplikasi dan kematian, sehingga "Need for help" tepat digunakan pada klien yang mengalami abortus inkomplet.

Selain menggunakan konsep teori need for help dari Wiedenbach pada kasus kelolaan ini juga menggunakan teori self care yang dikembangkan oleh Orem. Menurut Orem (2007) self care merupakan kemampuan individu untuk memprakarsai dirinya dalam melakukan perawatan diri sendiri dalam rangka mempertahankan kehidupan, kesehatan dan kesejahteraan. Model konsep Self care dari Orem merupakan suatu pendekatan yang dinamis, dimana perawat melakukan asuhan keperawatan untuk meningkatkan kemampuan klien dalam merawat dirinya sendiri. Self care yang dilakukan secara efektif dapat membantu menjaga fungsi tubuh serta berkontribusi seperti pada perkembangan individu. Supportif educatif yang diberikan pada klien dengan abortus inkomplet dapat meningkatkan pengetahuan klien tentang kesehatan reproduksi seperti mempersiapkan kondisi baik fisik dan mental pada kehamilan yang akan datang.

\section{HASIL}

Tutik Rahayu - Model Asuhan Keperawatan pada Klien dengan Abortus Inkomplet Menggunakan Pendekatan Need for Help Wiedenbach dan Self Care Orem 
Jurnal Ilmu Keperawatan Maternitas, Vol 1 No 2, Nov 2018/ page 31-42

Implementasi yang dilakukan oleh perawat yang pada dasarnya memberikan bantuan fisiologis dan psikologis untuk menciptakan kenyamanan bagi klien dalam pelaksanaan tindakan keperawatan yaitu mengkaji sumber dan sifat nyeri dengan menanyakan pada klien bagian mana yang dirasakan nyeri, kapan waktunya, nyeri yang diaraskan seperti apa, mengobservasi keadaan umum dan tanda-tanda vital, Menjelaskan tentang penyebab nyeri bahwa nyeri yang dialami klien disebabkan oleh masih adanya sisa jaringan didalam rahim sehingga rahim berkontraksi untuk berusaha mengeluarkan sisa jaringan yang dianggap benda asing, mengobservasi skala nyeri (dengan skala 010), Mengajarkan dan anjurkan menggunakan teknik pernapasan dan relaksasi, serta distraksi dengan menganjurkan pada klien untuk menarik nafas panjang melalui hidung dan mengeluarkan perlahan-lahan lewat mulut jika nyeri sedang berlangsung, menjelaskan pada klien tentang tehnik distraksi yang bisa digunakan untuk mengurangi nyeri seperti mengobrol dengan suami atau keluarga, Menganjurkan klien untuk istirahat yang cukup, Memberikan analgesik pada klien.

Diagnosa keperawatan cemas berhubungan dengan krisis situasi dan kurang pengetahuan tentang prosedur tindakan kuretase merupakan diagnosa keperawatan yang dapat muncul pada klien dengan abortus inkomplit. Cemas adalah suatu keadaan dimana individu atau kelompok mengalami suatu perasaan gelisah dan aktivasi sistem saraf autonom dalam berespon terhadap ancaman yang nonspesifik, tetapi individu mungkin dapat mengidentifikasi situasi (misalnya akan operasi atau kanker) (Carpenito, 2006).

Untuk mengatasinya masalah keperawatan cemas maka disusun rencana keperawatan yang bertujuan agar kecemasan klien dapat berkurang, klien dapat beradaptasi sehingga dapat kooperatif terhadap prosedur yang akan dilakukan. Adapun secara garis besar tindakan keperawatan meliputi
Memberikan dukungan mental dengan memberikan support dan menemani klien dan menganjurkan klien untuk tidak terlalu khawatir terhadap prosedur tindakan yang akan dilakukan dengan memberikan penjelasan dari tujuan tindakan kuretase, memberikan informasi tentang kondisi yang dialaminya, menjelaskan setiap prosedur yang akan dilakukan termasuk tindakan kuretase dengan memberikan informasi bahwa kuret akan dilakukan dan sebelumnya klien akan dilakukan anestesi sehingga klien tidak sadar saat kuret dilakukan, memotivasi keluarga untuk mendampingi klien, memberikan kesempatan klien untuk mengungkapkan perasaannya. menganjurkan klien untuk berdoa dan berserah diri kepada Allah SWT. Dari evaluasi yang telah dilakukan setelah diberikan tindakan keperawatan maka kecemasan dapat teratasi, dan klien dapat bersikap kooperatif terhadap tindakan medis maupun keperawatan yang dilakukan untuk menolong klien.

Diagnosa keperawatan berduka berhubungan dengan kehilangan janin sekunder terhadap abortus inkompletus dapat ditegakkan pada klien dengan abortus inkomplit, karena klien mengalami keadaan berduka dan kesedihan akibat dari keguguran dan kehilangan janin yang mereka alami.

Untuk mengatasi rasa berduka yang dialami klien maka dilakukan implementasi keperawatan yang bertujuan agar klien dan keluarga mampu mengungkapkan, klien dan keluarga mampu mengungkapkan perasaan dan kebutuhan berkenaan dengan persetujuan tindakan yang akan dilakukan. Adapun implementasi keperawatannya adalah: Memberikan kesempatan klien/ keluarga baik secara verbal maupun non verbal dalam mengungkapkan rasa berduka akibat kehilangan janinnya, mendengarkan keluhan klien dengan sungguh-sungguh, menjelaskan tentang kondisinya yang dialami klien, menjelaskan masih adanya harapan klien untuk dapat hamil kembali,

Tutik Rahayu - Model Asuhan Keperawatan pada Klien dengan Abortus Inkomplet Menggunakan Pendekatan Need for Help Wiedenbach dan Self Care Orem 
Jurnal Ilmu Keperawatan Maternitas, Vol 1 No 2, Nov 2018/ page 31-42

menggunakan komunikasi terapeutik dan keterampilan konseling untuk mendukung respons berduka, membantu keluarga dan membantu dalam membuat keputusan.

Pada fase pemeliharan yaitu pasca kuret diagnosa keperawatan yang dapat muncu diantaranya adalah keterbatasan mobilitas fisik berhubungan dengan pengaruh anestesi. Diagnosa keperawatan ini muncul karena adanya data seperti klien mengeluh pusing pasca tindakan kuret, klien belum mampu beraktifitas seperti berjalan secara mandiri, klien harus diantar menggunakan brankat untuk menuju ruang perawatan pasca menjalani prosedur kuret dan klien belum mampu melaksanakan pemenuhan kebutuhan berpakaian dan personal higiene secara mandiri. Etiologi dari diagnosa keperawatan ini adalah adanya efek dari anestesi. Klien saat dilakukan tindakan bedah mendapatkan anestesi intravena yaitu diberikan diazepam $5 \mathrm{mg}$ dan sulfas atropin 0,25 mg. Jenis obat ini memiliki efek samping diantaranya berupa sakit kepala, pusing diare, mual dan muntah. Untuk mengatasi diagnosa keperawatan keterbatasan mobilitas fisik berhubungan dengan efek dari anestesi maka implementasi keperawatan dilakukan dengan tujuan klien dapat beraktifitas mandiri secara bertahap.

Diagnosa keperawatan sejahtera yaitu potensial peningkatan pengetahuan pada klien dan keluarga dalam perawatan kehamilan yang akan datang juga dapat ditegakkan karena klien mengungkapkan adanya keinginan untuk mendapatkan informasi tentang apa saja yang perlu dipersiapkan dan dilakukan untuk menghadapi kehamilan yang akan datang. Penelitian yang dilakukan oleh Sejourne, Callahan, dan Charbol,(2010), tentang apa yang diinginkan perempuan setelah mengalami keguguran, ditemukan hasil penelitian yaitu, sebagian besar perempuan menginginkan adanya support sosial, adanya penyediaan informasi yang baik dan edukasi dari petugas kesehatan tentang apa yang harus dilakukan pasca mengalami keguguran.

\section{PEMBAHASAN}

Pengelolaan klien abortus inkomplet dibagi menjadi dua fase yaitu akut dan pemeliharan. Pada fase akut penulis mengaplikasikan teori need for help Wiedenbach. Dalam teorinya, Wiedenbach mengemukakan tentang aspek kiat atau seni (praktik) dalam keperawatan, dimana individu memerlukan bantuan karena stimulasi perilaku. Menurut Wiedenbach keperawatan klinik mempunyai 4 komponen yaitu: 1) filsafat (philosophy); 2) tujuan atau kemanfaatan atau kegunaan (purpose); 3) praktik; 4) kiat atau seni (art). Teori keperawatan Ernestine Wiedenbach dikenal sebagai "the helping art of clinical nursing".

Praktik keperawatan adalah tindakan yang diamati dan dipengaruhi oleh keyakinan dan perasaan untuk memenuhi kebutuhan klien yang membutuhkan bantuan. Praktek keperawatan memiliki 3 komponen yaitu 1) identifikasi kebutuhan klien 2) pertolongan yang diberikan pada klien 3) validasi atau evaluasi dari tindakan yang dilakukan. Pada identifikasi kebutuhan klien dengan abortus inkomplet, langkah awal yang harus dilakukan perawat yaitu perawat harus benar benar mampu mengenali perilaku yang ditunjukkan klien sehingga dapat mengidentifikasi kebutuhan klien, seperti adanya risiko defisit volume cairan akibat adanya pengeluaran pervaginam yaitu perdarahan yang berasal dari adanya sisa plasenta dalam uterus, adanya rasa nyeri akibat dari kontraksi uterus dan adanya kecemasan berkaitan dengan prosedur medis yang harus dijalani seperti kuretase dan berduka akibat kehilangan janin.

Langkah selanjutnya dalam identifikasi adalah perawat mengeksplorasi kemampuan klien dalam menyelesaikan masalah. Bila klien mengindikasikan ketidakmampuan berarti klien berada dalam 
Jurnal Ilmu Keperawatan Maternitas, Vol 1 No 2, Nov 2018/ page 31-42

kondisi membutuhkan bantuan. Bantuan atau pelaksanaan intervensi keperawatan direncanakan dengan tujuan memberikan yang terbaik untuk memenuhi kebutuhan klien dan keluarganya.

Pengelolaan klien pada fase pemeliharan digunakan teori self care Orem. Teori self care Orem ini dapat digunakan dalam memberikan asuhan keperawatan dan membantu hubungan antara perawat-klien dengan lingkungannya yang berdampak pada status kesehatan serta kebutuhan akan keperawatan. Didalam memandirikan klien, pelayanan keperawatan yang diberikan diklasifikasikan pada tiga sistem keperawatan (Orem, 2001) yaitu, sistem Wholly atau Totally compensatory nursing system, tindakan keperawatan diberikan dan dibutuhkan ketika perawat harus menjadi peringan bagi ketidakmampuan total seorang pasien dalam hubungan kegiatan merawat yang membutuhkan tindakan-tindakan penyembuhan dan manipulasi. Perawat mengambil alih pemenuhan kebutuhan self carenya secara menyeluruh kepada pasien yang tidak mampu melakukannya.

Sistem kedua yaitu Partially atau Partly compensatory nursing system: Perawat mengambil alih beberapa aktifitas yang tidak dapat dilakukan oleh pasien dalam memenuhi kebutuhan self carenya, dijalankan pada saat, baik perawat dan pasien menjalankan ukuran-ukuran perawatan atau tindakan-tindakan lain yang melibatkan tugas-tugas manipulatif atau penyembuhan.

Sistem yang ketiga adalah Supportif atau Educatif nursing system: Perawat memberikan pendidikan kesehatan atau penjelasan untuk memotivasi melakukan self care, tetapi yang melakukan self care adalah pasien sendiri. Kehamilan merupakan hal yang diharapkan pada setiap pasangan yang baru menikah atau pada keluarga yang ingin merencanakan memiliki anak lagi. Para pasangan tentunya mendambakan bahwa kehamilan yang dialami dapat berjalan dengan lancar tanpa mengalami komplikasi, namun sayangnya tidak semua harapan itu dapat terwujud. Sebagian dari perempuan yang hamil ada yang mengalami masalah seperti terjadi abortus inkomplet (Brief, 2008).

Seorang calon ibu atau ibu yang mengalami keguguran tentu akan mengalami perasaan berduka karena kehilangan janin yang sebenarnya sangat diharapkan kehadirannya ditengah keluarga mereka (Epstein, Leichtenttrif, Benyamini, 2009). Apalagi bila penantian kehamilan ini sudah cukup lama waktunya. Selain itu perasaan berduka akibat kehilangan janin juga dapat dialami bagi pasangan yang baru menikah kerena kehamilannya sangat diharapkan dan hal ini biasanya sebagai bukti bahwa mereka mampu menghasilkan keturunan sehingga akan dapat meningkatkan konsep diri pada pasangan. Persiapan dan penyesuaian diri yang sudah ibu lakukan selama hamil dan ketika ternyata kehamilannya tidak dapat dipertahankan menjadikan hal ini sebagai stressor yang berat tidak hanya bagi ibu, tetapi juga pasangan dan anak-anak mereka yang lain.

Respon keguguran sangat beragam bagi setiap perempuan, ada yang menunjukkan dampak emosional yang minimal, tetapi bagi sebagian perempuan dapat mengalami depresi dan kecemasan pasca keguguran (Rowland \& Cristine, 2010). Rendahnya penyesuaian diri yang dimiliki perempuan pasca keguguran dapat berdampak pada aspek psikologis, sosial dan reproduksi. Pada tingkat psikososial, adanya riwayat gangguan mental berhubungan dengan ketidakmampuan menyesuaikan diri pada perempuan setelah mengalami keguguran (Rowland \& cristine, 2010). Kondisi depresi dan kecemasan lebih besar ditunjukkan bagi perempuan yang belum memiliki anak dibanding yang sudah mempunyai anak (Rowland \& Cristine, 2010). 
Jurnal Ilmu Keperawatan Maternitas, Vol 1 No 2, Nov 2018/ page 31-42

Beberapa alasan klien datang kerumah sakit untuk meminta pertolongan adalah klien mengalami perdarahan, perdarahan banyak berupa gumpalan dan disertai mulas-mulas pada perut bagian suprapubik. Pada pemeriksaan inspekulo terlihat ada perdarahan, osteum uteri eksternal terbuka dan ada yang menutup, terlihat sebagian jaringan. Tanda dan gejala dari abortus inkompletus adalah terdapat perdarahan bisa sedikit atau banyak disertai gumpalan (Snell, 2009), rasa mulas atau kontraksi bertambah, osteum uteri eksternal terbuka, pada pemeriksaan vaginal jaringan dapat diraba dalam kavum uteri atau kadang sudah menonjol dari eksternum atau sebagian jaringan keluar dan perdarahan tidak berhenti sebelum sisa janin dikeluarkan dan dapat menyebabkan syok (Tarigan, 2004).

Faktor yang menyebabkan terjadinya abortus inkompletus, lebih dari $80 \%$ abortus terjadi pada 12 minggu pertama dan setengahnya disebabkan anomali kromosom. Resiko abortus spontan meningkat seiring paritas serta usia ibu dan ayah (Alamsyah, 2009). Kasus abortus inkomplit dapat terjadi pada usia ibu antara 20-40 tahun dan usia pasangan antara 2443 tahun. Berdasarkan faktor umur secara teori satu klien dan pasangan merupakan resiko tinggi untuk terjadinya abortus. Frekuensi abortus secara klinis terdeteksi meningkat dari $12 \%$ pada wanita usia kurang dari 20 tahun dan menjadi $26 \%$ pada mereka yang usianya lebih dari 40 tahun. Untuk usia ayah yang sama peningkatannya adalah 12 sampai $20 \%$ (Alamsyah, 2009). Wanita dengan resiko abortus meningkat sesuai umur. Resiko abortus wanita usia 2024 tahun adalah 8,9\%, wanita berumur 45 tahun atau lebih resiko terjadinya abortus meningkat menjadi $74,7 \%$. Diduga makin tinggi usia makin tinggi kelainan pada kromosom ovarium. Hal ini dapat diterangkan dengan peningkatan angka kelainan kromosom pada usia yang lebih tinggi. Wanita subfertil mempunyai resiko lebih tinggi untuk abortus ( Wijayanegara,
2009). Mekanisme pasti yang menyebabkan abortus tidak selalu jelas, tetapi pada bulanbulan awal kehamilan, ekspulsi ovum secara spontan hampir selalu didahului oleh kematian mudigah atau janin. Karena itu pertimbangan etiologis pada abortus dini antara lain mencakup pemastian kausa kematian janin (apabila mungkin) (Alamsyah,2009).

Etiologi yang lain seperti faktor ibu misalnya adanya penyakit kronis TBC, pnemonia akut, thpus abdominalis, toksoplasmosis, gangguan endokrin, malnutrisi, keracunan obat, gangguan hormonal, kelainan anatomi alat reproduksi mosional seperti kista dan mioma, faktor psikologis dan stress emosional, paparan alkohol dan rokok (Alamsyah, 2009, Khusnah, 2010).

Diagnosa keperawatan yang muncul pada fase akut antara lain adalah risiko defisit volume cairan berhubungan dengan perdarahan pervagina. Kekurangan volume cairan adalah suatu keadaan dimana seorang individu yang tidak berpuasa mengalami resiko dehidrasi vaskuler intestitial atau intravaskuler (Carpenito, 2006). Pada abortus inkomplet manifestasi yang dapat terjadi adalah adanya perdarahan bisa sedikit atau banyak dan dapat berupa bekuan darah. Osteum uteri eksternum membuka, pada pemeriksaan vaginal jaringan dapat diraba dalam cavum uteri atau kadang-kadang sudah menonjol atau sebagain jaringan keluar. Perdarahan tidak berhenti sebelum sisa janin dikeluarkan (Murray \& Mckinney,2007).

Adapun untuk mengatasi masalah risiko defisit volume cairan berhubungan dengan perdarahan pervagina diantaranya adalah Melakukan pengkajian terkait dengan riwayat perdarahan, durasi, jumlah, warna dan karakteristik perdarahan, mengukur tanda-tanda vital, mengkaji kontraksi uterus, mendeteksi adanya tanda-tanda syok menganjurkan klien untuk rehidrasi oral dengan minum yang cukup yang terdiri dari teh manis dan hangat, cairan yang 
Jurnal Ilmu Keperawatan Maternitas, Vol 1 No 2, Nov 2018/ page 31-42

mengandung elektrolit dan air putih, memantau balance cairan, memantau kepatenan akses cairan intravena memantau nilai laboratorium seperti hemoglobin, hematrokrit, eritrosit, trombosit.

Implementasi intra bedah dan pasca kuret diantaranya adalah membantu mempersiapkan prosedur kuret seperti menyiapkan alat dan obat obatan untuk anestesi seperti diazepam $5 \mathrm{mg}$, sulfasatropin $0,25 \mathrm{mg}$ (IV), lidokain $40 \mathrm{mg}$ untuk anestesi paracervical, menganjurkan klien untuk mengosongkan kandung kemih sebelum dilakukan kuret, membantu memposisikan klien dengan posisi litotomi selama prosedur kuret dilakukan, memberikan 02 kanul 5 liter/menit pada klien dan mengobservasi kepatenan jalan nafas, mengukur tanda-tanda vital klien sebelum pelaksanaan kuret, melakukan kolaborasi pemberian methergin 0,2 mg (IM) untuk mencegah terjadinya perdarahan, membantu, mengukur tandatanda vital pasca kuret, melakukan observasi adanya perdarahan pasca kuret, melakukan observasi kontraksi uterus pasca kuret, memberikan motivasi pada klien untuk rehidrasi cairan oral secara adekuat kurang lebih $1500 \mathrm{cc} /$ hari.

Diagnosa keperawatan lain yang muncul pada klien dengan abortus inkomplit yaitu nyeri akut berhubungan dengan kontraksi uterus, sisa hasil konsepsi. Nyeri akut adalah keadaan dimana individu mengalami dan melaporkan adanya rasa ketidaknyamanan yang hebat atau sensasi yang tidak menyenangkan selama enam bulan atau kurang (Carpenito,2006). Klien mengeluh nyeri pada perut bagian bawah, nyeri seperti diremas-remas, skala nyeri bervariasi antara 5-7. Rasa nyeri juga disertai adanya keluaran darah dari jalan lahir. Nyeri kram suprapubik terjadi akibat kontraksi uterus dalam usaha mengeluarkan isi uterus. Pada awalnya nyeri cenderung ringan dan intermiten, tetapi secara bertahap menjadi lebih hebat. Perdarahan pervaginam merupakan gejala yang paling khas dari abortus inkompletus. Jumlah perdarahan cenderung lebih banyak daripada darah haid biasa. Perdarahan mungkin hebat dan bahkan cukup berlebihan untuk menyebabkan syok hipovolemik (Taber,2000). Sebuah penelitian kualitatif yang dilakukan oleh Maker dan Ogden (2003), menemukan thema yaitu partisipan mengungkapkan mengalami perdarahan yang datang secara tiba-tiba pada malam hari disertai rasa tidak nyaman dan nyeri yang berbeda dari yang pernah ia rasakan dan hal ini belum pernah partisipan alami sebelumnya.

Implementasi dilakukan oleh perawat yang pada dasarnya memberikan bantuan fisiologis dan psikologis untuk menciptakan kenyamanan bagi klien dalam pelaksanaan tindakan keperawatan yaitu mengkaji sumber dan sifat nyeri dengan menanyakan pada klien bagian mana yang dirasakan nyeri, kapan waktunya, nyeri yang diaraskan seperti apa, mengobservasi keadaan umum dan tanda-tanda vital, Menjelaskan tentang penyebab nyeri bahwa nyeri yang dialami klien disebabkan oleh masih adanya sisa jaringan didalam rahim sehingga rahim berkontraksi untuk berusaha mengeluarkan sisa jaringan yang dianggap benda asing, mengobservasi skala nyeri (dengan skala 010), Mengajarkan dan anjurkan menggunakan tehnik pernapasan dan relaksasi, serta distraksi dengan menganjurkan pada klien untuk menarik nafas panjang melalui hidung dan mengeluarkan perlahan-lahan lewat mulut jika nyeri sedang berlangsung, menjelaskan pada klien tentang teknik distraksi yang bisa digunakan untuk mengurangi nyeri seperti mengobrol dengan suami atau keluarga, Menganjurkan klien untuk istirahat yang cukup, Memberikan analgesik pada klien.

Diagnosa keperawatan cemas berhubungan dengan krisis situasi dan kurang pengetahuan tentang prosedur tindakan kuretase merupakan diagnosa keperawatan yang dapat muncul pada klien dengan abortus inkomplit. Cemas adalah suatu 
Jurnal Ilmu Keperawatan Maternitas, Vol 1 No 2, Nov 2018/ page 31-42

keadaan dimana individu atau kelompok mengalami suatu perasaan gelisah dan aktivasi sistem saraf autonom dalam berespon terhadap ancaman yang nonspesifik, tetapi individu mungkin dapat mengidentifikasi situasi (misalnya akan operasi atau kanker) (Carpenito, 2006).

Penatalaksanaan pada abortus inkompletus dapat dilakukan dengan tehnik medis maupun bedah. Tehnik bedah dilatasi serviks diikuti oleh evakuasi uterus dapat berupa kuretase, aspirasi vakum, dilatasi dan evakuasi ( $D \& E$ ), dilatasi dan ekstrasi (D\&X). Tehnik kuretase dapat dengan menggunakan kuret tajam maupun vakum (Irianti,2009). Untuk mengurangi komplikasi kuretase seperti perforasi usus, laserasi serviks, perdarahan, pengeluaran janin dan plasenta yang tidak lengkap dan infeksi, maka kuretase dianjurkan pada kehamilan dibawah 14 minggu. Untuk usia gestasi diatas 16 minggu, dilakukan dilatasi dan evakuasi (D\&E). Tindakan ini berupa dilatasi serviks lebar diikuti oleh distruksi dan evakuasi mekanis bagian-bagian janin. Setelah janin seluruhnya dikeluarkan, dengan menggunakan kuret vacum berlubang besar untuk mengeluarkan plasenta dan jaringan yang tersisa. Dilatasi dan ekstrasi (D\&X) serupa dengan (D\& E), kecual pada (D\& X) bagian janin pertama kali diektrasi melalui serviks yang telah membuka untuk mempermudah tindakan. Pemasangan laminaria dapat dilakukan untuk pembukaan serviks (Irianti, 2009).

Tehnik medis dalam penatalaksanaan abortus yaitu dengan pemberian oksitosin dalam intrvena cairan, prostalgladin dengan berbagai analognya seperti prostalgladin E2, Prostaglandin F2a dll dan misoprostol banyak dipakai sebagai obat induksi abortus. Prostagladin dapat bekerja secara efektif pada serviks dan uterus apabila a). dimasukkan ke vagina sebagai supositoria atau pesarium tepat didekat serviks. b). Diberikan sebagai gel melalui sebuah kateter ke dalam kanalis serviksalis dan bagian paling bawah uterus. c). Disuntikan intramuskuler. d). Disuntikan kedalam kantong amnion melalui amniosentesis. e). diminum peroral (Irianti, 2009).

Untuk mengatasinya masalah keperawatan cemas maka disusun rencana keperawatan yang bertujuan agar kecemasan klien dapat berkurang, klien dapat beradaptasi sehingga dapat kooperatif terhadap prosedur yang akan dilakukan. Adapun secara garis besar tindakan keperawatan meliputi Memberikan dukungan mental dengan memberikan support dan menemani klien dan menganjurkan klien untuk tidak terlalu khawatir terhadap prosedur tindakan yang akan dilakukan dengan memberikan penjelasan dari tujuan tindakan kuretase, memberikan informasi tentang kondisi yang dialaminya, menjelaskan setiap prosedur yang akan dilakukan termasuk tindakan kuretase dengan memberikan informasi bahwa kuret akan dilakukan dan sebelumnya klien akan dilakukan anestesi sehingga klien tidak sadar saat kuret dilakukan, memotivasi keluarga untuk mendampingi klien, memberikan kesempatan klien untuk mengungkapkan perasaannya. menganjurkan klien untuk berdoa dan berserah diri kepada Allah SWT. Dari evaluasi yang telah dilakukan setelah diberikan tindakan keperawatan maka kecemasan dapat teratasi, dan klien dapat bersikap kooperatif terhadap tindakan medis maupun keperawatan yang dilakukan untuk menolong klien.

Diagnosa keperawatan berduka berhubungan dengan kehilangan janin sekunder terhadap abortus inkompletus dapat ditegakkan pada klien dengan abortus inkomplit, karena klien mengalami keadaan berduka dan kesedihan akibat dari keguguran dan kehilangan janin yang mereka alami. Berduka adalah suatu keadaan dimana individu atau keluarga mengalami respon manusia yang alami yang melibatkan reaksi psikososial dan fisiologis pada kehilangan aktual atau yang dirasakan (orang, objek, fungsi, status, hubungan) (Carpenito,2006).

Tutik Rahayu - Model Asuhan Keperawatan pada Klien dengan Abortus Inkomplet Menggunakan Pendekatan Need for Help Wiedenbach dan Self Care Orem 
Jurnal Ilmu Keperawatan Maternitas, Vol 1 No 2, Nov 2018/ page 31-42

Banyak perempuan yang mengalami keguguran mengungkapkan kesedihan akibat kehilangan bayinya, harapan dan gairah hidup (Swanson et al, 2006). Gejala seperti berduka, kecemasan, depresi, atau trauma dapat mereka alami dari hari pertama sampai satu tahun setelah mengalami keguguran (Swanson et al,2006). Penemuan dalam beberapa penelitian kualitatif menyebutkan bahwa pengalaman perempuan yang mengalami keguguran merupakan peristiwa yang yang sangat sulit dalam kehidupan mereka (Swanson et.al,2006). Para perempuan mendiskripsikan beberapa hal seperti berupaya mencari makna dari kehilangannya, kebingunan dan harapan terhadap kesehatan kehamilan dimasa yang akan datang, merasakan adanya kekosongan, rasa bersalah, kesedihan, mengharapkan dukungan, keinginan untuk mendengarkan dan pemberian informasi secara jujur tentang apa yang terjadi serta apa yang harus dilakukan dimasa yang akan datang (Swanson et al, 2006).

Untuk mengatasi rasa berduka yang dialami klien maka dilakukan implemetasi keperawatan yang bertujuan agar klien dan keluarga mampu mengungkapkan, klien dan keluarga mampu mengungkapkan perasaan dan kebutuhan berkenaan dengan persetujuan tindakan yang akan dilakukan. Adapun implementasi keperawatannya adalah: Memberikan kesempatan klien/ keluarga baik secara verbal maupun non verbal dalam mengungkapkan rasa berduka akibat kehilangan janinnya, mendengarkan keluhan klien dengan sungguh-sungguh, menjelaskan tentang kondisinya yang dialami klien, menjelaskan masih adanya harapan klien untuk dapat hamil kembali, menggunakan komunikasi terapeutik dan keterampilan konseling untuk mendukung respons berduka, membantu keluarga dan membantu dalam membuat keputusan.

Pada fase pemeliharan yaitu pasca kuret diagnosa keperawatan yang dapat muncu diantaranya adalah keterbatasan mobilitas fisik berhubungan dengan pengaruh anestesi. Diagnosa keperawatan ini muncul karena adanya data seperti klien mengeluh pusing pasca tindakan kuret, klien belum mampu beraktifitas seperti berjalan secara mandiri, klien harus diantar menggunakan brankat untuk menuju ruang perawatan pasca menjalani prosedur kuret dan klien belum mampu melaksanakan pemenuhan kebutuhan berpakaian dan personal higiene secara mandiri. Etiologi dari diagnosa keperawatan ini adalah adanya efek dari anestesi. Klien saat dilakukan tindakan bedah mendapatkan anestesi intravena yaitu diberikan diazepam $5 \mathrm{mg}$ dan sulfas atropin 0,25 mg. Jenis obat ini memiliki efek samping diantaranya berupa sakit kepala, pusing diare, mual dan muntah. Untuk mengatasi diagnosa keperawatan keterbatasan mobilitas fisik berhubungan dengan efek dari anestesi maka implementasi keperawatan dilakukan dengan tujuan klien dapat beraktifitas mandiri secara bertahap.

Diagnosa keperawatan sejahtera yaitu potensial peningkatan pengetahuan pada klien dan keluarga dalam perawatan kehamilan yang akan datang juga dapat ditegakkan karena klien mengungkapkan adanya keinginan untuk mendapatkan informasi tentang apa saja yang perlu dipersiapkan dan dilakukan untuk menghadapi kehamilan yang akan datang. Penelitian yang dilakukan oleh Sejourne, Callahan, dan Charbol (2010), tentang apa yang diinginkan perempuan setelah mengalami keguguran, ditemukan hasil penelitian yaitu, sebagian besar perempuan menginginkan adanya support sosial, adanya penyediaan informasi yang baik dan edukasi dari petugas kesehatan tentang apa yang harus dilakukan pasca mengalami keguguran.

Dalam melaksanakan asuhan keperawatan berdasarkan teori keperawatan menurut Wiedenbach seorang perawat harus mampu mengidentifikasi kebutuhan passien terhadap bantuan dengan melakukan 
Jurnal Ilmu Keperawatan Maternitas, Vol 1 No 2, Nov 2018/ page 31-42

langkah-langkah seperti mengobservasi kesesuaian perilaku klien terhadap ketidaknyamanan yang ia rasakan, mengeksplorasi makna gejala perilaku yang ditunjukkan klien, menentukan penyebab dari ketidaknyamanan tersebut, mengidentifikassi kemampuan klien dalam menyelesaikan masalah atau kebutuhan klien terhadap bantuan dari perawat atau profesi kesehatan lain. Jika klien membutuhkan bantuan untuk menyelesaikan permasalahannya, perawat memfasilitasi perencanaan pelayanan medis dan juga membuat perencanaan keperawatan berdasarkan kebutuhan dan keinginan klien. Kemampuan perawat dalam mengeksplorasi informasi dari klien sangat bervariasi. Perawat dituntut untuk berfikir kritis dalam berinteraksi dengan klien dengan mengembangkan seni dalam memberikan bantuan.

Menurut Orem keperawatan merupakan rangkaian aktifitas yang bersifat therapeutik didasari oleh teori keperawatan. Sistem keperawatan diartikan sebagai produk atau hasil dari aktifitas perawat sebagai agent self care pasien serta memenuhi kebutuhan self care secara therapeutik. Didalam sistem keperawatan, perawat memberi gambaran, merancang dan memfasilitasi kebutuhan self care pasien dan mencari cara bentuk terapeutik perawat sehingga dapat mengeliminir self care defisit dari pasien. Terdapat tiga kategori sistem keperawatan yang mendasari perawat untuk memberikan bantuan, yaitu: total, partial dan supportif.

\section{REFERENSI}

Abraham, Petter. (2010). Panduan kesehatan dalam kehamilan,Alih bahasa Victor setyadi, editor Lyndon Saputra, penerbit Kharisma,Jakarta

Alam Naureen. (2007). Obstetrics and gynecology, By Mosby, Inc, an affiliate of Elsevier
Alamsyah M. (2009). Abortus berulang; editor, Budi Handono, Firman F.w, Johanes C; PT refika Aditama. Bandung

Anonim. (2011). Management of misscarriage and ectopic pregnancy, Emergency nurse,Volume 9,No : 7

Azhari. (2002). Masalah abortus dan kesehatan reproduksi perempuan. Bagian Obstetri dan Ginecologi FK. Unsri Palembang.

Benson.C.R, Pernol,L.M. (2008). Buku saku obstetric dan ginecologi; alih bahasa,susiani Wijaya; editor edisi bahasa Indonesia Srie Sisca, - Ed 9. EGC. Jakarta

Brierf.N. (2008). Grief following misscariage : A comprehensive riview of the literature, Journal of women health, volume 17 , no : 3

Bui Quynh. (2011). Management options for early incomplete miscarriage, American Family Physician, Volume 83, No : 3.

Carpenito. L.J. (2006). Buku saku diagnosa keperawatan alih bahasa Yasmin Asih. Editor Monica Ester. Penerbit EGC. Jakarta.

Chandranita, Fajar, Manuaba. (2004). Gawat darurat obstetric ginekologi dan obstetric ginekologi social untuk profesi bidan, EGC, Jakarta.

Depkes RI. (2009). Profil kesehatan Indonesia 2008, Depkes, Jakarta

E. Rousell, Kerchmer, Orford. (2011). The psychological impact of recurrent mis cariage and the rate of counselling at a pre-pregnancy counselling clinik. Journal of Reproduksi and infant Psychology. Vol 19 No. 1. 
Jurnal Ilmu Keperawatan Maternitas, Vol 1 No 2, Nov 2018/ page 31-42

Epsteint, Leichtenttrif, Benyamini.(2009).

The experience of misscarriage in first pregnancy : the women voice, Death studies,33: 1-29

Gilbert, Harmon Judith Smith. (2003). Manual of high risk pregnancy and delivery. 3rd Mosby, St, Louis, Missouri.

Husnah. (2010). Faktor-faktor yang mempengaruhi kejadian abortus di RSUD. Lamaddukelleng Sengkang Kabupaten Wajo Periode Januari - Juni 2010. Jurnal Medi Kebidanan Poltekes Makasar No. 7, Edisi Juli - Desember 2010.

Indrayani. (2011). Buku ajar asuhan kehamilan, CV Trans Info Media, Indonesia

Irianti S. (2009). Abortus berulang; editor , Budi Handono, Firman F.w, Johanes C; PT refika Aditama. Bandung

Kaunonen, M. (2000). Support for a family in grief. University of Tempere.

Mardhiyah, Prawirodihardjo, Tiro E. (2011). Analisa derajat depresi menggunakan parameter Zung Self Rating Depresian pada abortus

Maker. C and Odgen. J. (2003). The mis carrage experience more than just a trigger to psychological morbidity. Psycology and Health. Vol. 18 no. 3. Pp 403-415.

Marrines, Tommy A. (1994). A nursing thourist and their work. 3rd cd St. Louis Company.

Maryunani , Yulianingsih. (2009). Asuhan keperawatan dalam kebidanan. Trans Info Media, Jakarta
Mc Ewen. (2007). Theoritical Basic for Nursig. Ed. 3. Lpincott Williams \& wilkins. Philadelphia.

Murray, McKinney.(2007). Foundation of maternal newborn nursig 4 th edition, Saunders An imprint of Elsevier Inc

Noerjasin $H$, Handono $B$, Kuwino $H$, Wirakusuma F. (2010). The correlation between serum protein. Bcl 2 and caspase 3 level.

Norwitz, Schorge. (2008). At a glance obstetry and gynecology 2th, penerbit Airlangga dan pusat berbukuab Depdiknas

Parisaei, Shailendra, Dutta, Broadbent. (2008). Obstetrics and gynaecology, Mosby Elseivier

Paton, F.,Wood, R., Bor, R., Nitsun, M., (2000) Grief in miscarriage patients and satisfaction with care in a London hospital, Journal of Reproductive and infant psychology, Vol. 17, No. 3.

Penyebab angka kematian ibu di Indonesia. (2012, Maret). http \\www.tribunnews.com $\backslash 2012 \backslash 03 \backslash 08 \backslash$

Rowlands I, Lee Christina. (2010). Adjusment after miscarriage predicting positive mental health trajectories among young Australians women. Psycology and Medicine. Vol. 15. No. 1. Januari 2010. $34-49$.

Rowlands I, Lee Christina. (2010). The silence was deafening : Social and health service support after mis carriage. Journal of Reproductive and Infant Psycology. Vol 28, No. 3 August 2010, $274-286$.

Sugiarti. K.R. (2010). Analisis faktor-faktor yang mempengarui abortus di RSIA. Amanah Sumpyuh kelurahan 
Jurnal Ilmu Keperawatan Maternitas, Vol 1 No 2, Nov 2018/ page 31-42

Bokopura Kecamatan Sumpyuh

kabupaten Bayumas.

Sejourne, Callahan, dan Charbol,(2010).

Supporting following misscarriage : what women want, Journal of Reproductive and Infant Psychology, Vol : 28, No : $4,403-411$

Swanson, M.K. (1998). Caring made visible. Journal Creatif Health Care Management.

Swanson, K.M. (1993). Nursing as informed caring for the well being of others. Journal of Nursing Scholarship.

Swanson. M.K. at. Al. (2006). Context and evaluation of women's responses to mis caring during the first year after loss. Research in Nursing and Health. 30, 2-16.

Tarigan. (2009). Perdarahan selama kehamilan. Universitas Sumatra Utara

The helping art of clinical nursing. (2012, January $31)$, http://nursingcurrent.com

Tomey and Alligood. (2006). Nursing theorist and their work theory of caring. Mosby Inc.

Varney, Kreibs, Gegor. (1998). Buku saku bidan (Varney's poket midwife), EGC, Jakarta.

Wijayanegara, H. (2009). Abortus berulang; editor, Budi Handono, Firman F.w, Johanes C; PT refika Aditama. Bandung 